forestry profession cannot avoid the environment debate and cannot avoid it being public. But why should it try to avoid these aspects in the first place? We should welcome the public's involvement in forestry because it constitutes the best potential support for forest management in Canada. The environmental debate provides an opportunity for promoting integrated forest management.

At a time when the world is discovering and adopting the concept of sustained development, the forestry profession should make the public aware that we, in forestry, have promoted the concept of sustained yield for many decades. Also when many groups want more attention paid to wildlife habitat, wilderness areas, aesthetics of the forest, how many of these know that foresters have developed the concepts of multiple use of forest land and integrated forest management?

Clearly, the forestry profession was among the first to be concerned with the quality of the forest environment, but we have to recognize that effective action in the field has not always been easy and must demonstrate how adequate forest management can improve the forest environment.

Why is it not the case more often? Partly because sometimes the practice of forestry has not always been up to standards and some mistakes have been made. But partly also because we have not taken, on our own initiative, an active role vis à vis these issues and other groups have filled the void.

The quality of the forest environment will be a major question for years to come and the forestry profession has to associate itself with it, be involved in shaping environmental policies and take part in their implementation, otherwise others will do it in our place. It won't go away. That is why the CIF is asking that the forestry profession be represented at the roundtables on the economy and the environment.

Claude Godbout, for. eng. President
En fait, au moment même où le monde entier découvre et adopte le concept du développement soutenu, la profession elle-même devrait démonter au grand public que nous, forestiers, proposons ce concept de rendement soutenu depuis déjà plusieurs décennies. De même, lorsque des groupes nombreux veulent attirer l'attention sur l'habitat de la faune, les régions sauvages, les aspects esthétiques de la forêt, combien savent que ce sont les forestiers qui ont élaboré les concepts d'utilisation multiple du territoire forestier et d'aménagement intégré des foréts?

Il est clair que la profession a été l'une des premières à s'intéresser à la qualité du milieu forestier. Mais nous devons aussi reconnaitre qu'il n'a pas toujours été facile d'agir et de démonter comment l'aménagement des forêts peut améliorer l'environnement forestier.

Pourquoi n'est-ce pas plus souvent le cas? En partie parce que quelquefois la pratique de la foresterie n'a pas été à la hauteur et que des erreurs ont été commises mais aussi, en partie, parce que nous n'avons pas toujours adopté, de notre propre initiative, un rôle "pro-actif" sur ces questions et que d'autres groupes ont occupé le vide que nous avons laissé.

La qualité du milieu forestier sera une question majeure au cours des prochaines années et la profession devra s'y associer, s'impliquer dans l'élaboration des politiques de l'environnement et prendre part à leur mise en force, sinon d'autres le feront à sa place. Le problème ne disparaîtra pas tout seul. Voilà pourquoi l'IFC-CIF demande que la foresterie soit représentée à la table ronde sur l'économie et l'environnement.

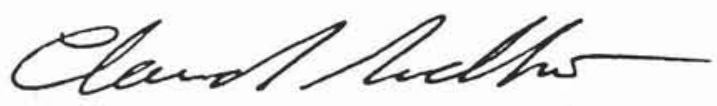

Claude Godbout, ing.f., M.B.A. Président

\title{
Report on 1988 Annual Meeting
}

\section{Resolutions}

Resolution $88.1 \quad$ Support to Nature Conservancy of Canada for the establishment and use of the Conservancy's data bases.

Action: Letter of general support written to Garry Glazier, Ex. Dir., Nature Conservancy of Canada by JHC, Nov. 4, 1988.

Resolution 88.2 Importance of Forest Research

Action: The resolution will be actioned by ongoing CIF/IFC activities including CIF/ IFC participation on the Steering Committee for IUFRO Congress, by coverage in Forestry Chronicle and by preparation of a Forestry Dialogue issue concerning the Congress.

Resolution 88.3 Congratulations to Hon. St. Germain on appointment of Minister responsible for forestry.
Action: Letter written to Hon. G. St. Germain, by A.J. Kayll, Sept. 16. A follow-up letter was sent to Hon. F. Oberle (Dec. 9) following his appointment as Minister responsible for forestry.

Resolution 88.4 Letter of congratulations to Hon. G. Merrithew.

Action: Letter sent by President, October 4, and acknowledged by Mr. Merrithew, November 4 .

Resolution 88.5 Defeated.

Resolution 88.6

Withdrawn

Resolution $88.7 \quad$ Financial support for Student Representatives at Annual Meetings.

Action: A letter was written to each Section containing a university to ascertain their interest and views on funding, December 14. 
Resolution 88.8 Annual Meeting Review

Action: A Task Force consisting of C. Geale, J. Benson, J. Munro, B. Haddon and J. Cayford has been established and will report at the 1989 Annual Meeting.

Resolution 88.9 Promotion of Private Woodlots

Action: The resolution was specifically referred to in a Jan. 23rd 1989 letter sent to DM's, federal provincial, and territorial, responsible for forestry and which included copies of resolutions 88.1, 88.2, 88.3, $88.4,88.7,88.8,88.9$, and 88.10 (Jan. 23. 1989).
A copy of letter was also sent to Antonio Dallarie, Fédération des Producteurs de Bois du Québec and Peter de Marsh, NB Federation of Woodlot Owners. (Jan. 26, 1989).

Resolution 88.10 Strategic Plans for the Forest Sector

Action: The resolution was sent to Hon. Vincent Kerrio, Chairman, CCFM on November 25. All other externally directed resolutions were also sent to Mr. Kerrio. EC scheduled to meet with Mr. Kerrio, March 7.

J.H. Cayford, R.P.F. 1989.03 .03

\section{POSITION ANNOUNCEMENT ASSISTANT PROFESSOR FOREST MANAGEMENT}

The Faculty of Forestry at the University of Toronto offers programs of study leading to the B.Sc.F., M.Sc.F. and Ph.D. degrees as well as a Diploma in Resource Management. Undergraduate and graduate teaching is focussed on forest management, forest biology an

The Faculty is moving to the new Earth Sciences Centre this year. This Centre, which will house the Faculty of Forestry and the Departments of Botany and Geology, will provide a modern, integrated environment for research and teaching.

Applications are invited for the position of Assistant Professor in FOREST MANAGEMENT. This is a tenure-stream position subject to final University approval.

The successful candidate will be responsible for undergraduate and graduate teaching in forest regulation and integrated resource management; graduate student supervision; and administrative duties. The Faculty is developing centres of strength in three areas of research - Forest Health; Forest Resource Management Systems; and Wood Protection. The successful candidate will be expected to unaterione Forest Resource Management Systems, and to cooperate actively with other acteric stafr.

Applicants for this position should possess a Ph.D. in forest management and be familiar with modelling and Geographic Information System technology, as applied to forest management. Applicants should be registered professional foresters or have the professional qualifications for membership in a professional forestry association.

Salary will be commensurate with the qualifications and experience of the successful candidate. The proposed appointment date is September $1,1989$.

The University of Toronto encourages both women and men to apply for positions. Preference will be given to Canadian citizens and permanent residents.

Interested and qualified individuals should submit their curriculum vitae and other relevan information. Three referees, who are acquainted with the work of the applicant, should be asked to forward letters of reference. The deadline for receipt of applications is

June 15, 1989. All documentation should be submitted tos

Dean J.R. Carrow

Faculty of Forestry

University of Toront

Toronto, Ontario

\section{Photogrammetrist $\$ 36,700-\$ 44,100$}

If you are self-motivated, consider this opportunity with the MINISTRY OF NATURAL RESOURCES, timber sales branch, to: provide forest-resources inventory development, analysis and operational trials to improve statistical precision, volume estimation and update-procedures' capability; work with forest-resources group to integrate data-collection procedures re improving forest-management database. Location: Sault Ste. Marie.

Qualifications: Detailed knowledge of statisticalsampling procedures, forest mensuration, photogrammetry and remote-imagery analysis; good practical knowledge of mensurational procedures for ground sampling and photo measurements; knowledge of photogrammetric instruments, imagery-data sources/analysis equipment and computer equipment; understanding of forestinventory data uses and existing procedures; demonstrated communication skills.

Please send application/resume, quoting file NR-2019/89, by May 26, 1989 to: Ministry of Natural Resources, Human Resources, P.O. Box 310, 747 Queen Street East, Sault Ste. Marie, Ontario, P6A 5 L8.

Equality of Opportunity for Employment

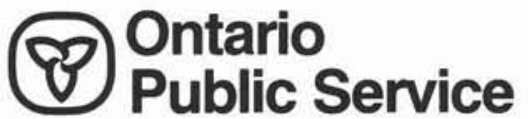

\section{Change of Address}

Date Section

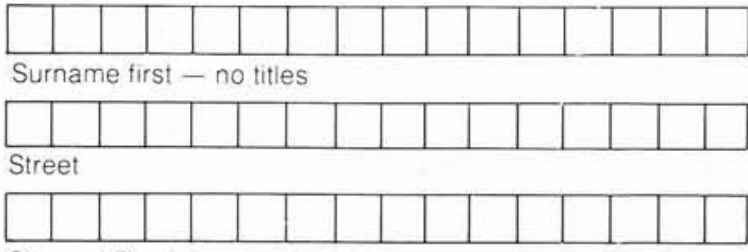

City and Province
Postal Code

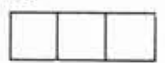

April 1989 The Forestry Chronicle
Changement d'adresse

Date Section

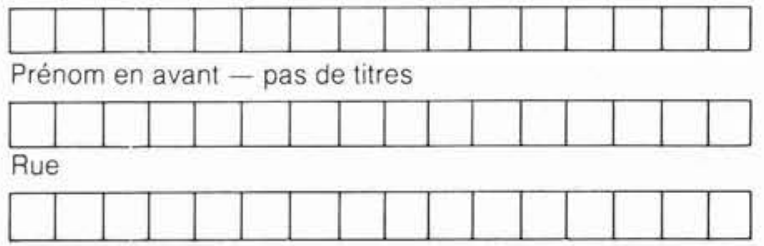

Ville et Province

Code Postale 